\title{
A VÁLLALKOZÓI SZERVEZŐDÉSEK SZEREPE A SZERZŐDÉSES KAPCSOLATOK TÁMOGATÁSÁBAN EGY MAGYAR ÁGAZAT TANULSÁGAI
}

\author{
THE ROLE OF BUSINESS ASSOCIATIONS IN THE GOVERNANCE OF \\ CONTRACTUAL RELATIONS \\ INSIGHTS FROM A HUNGARIAN INDUSTRY
}

Miként támogatják az ágazati-szakmai szerveződések a vállalkozások közötti szerződéses kapcsolatokat? A szerző egy magyar ágazatról készített, a Közép-dunántúli és a Közép-magyarországi régióban végzett terepmunkán alapuló esettanulmány segítségével keres magyarázatot arra, hogy (1) milyen szerződéstámogató funkciókat töltenek be a vállalkozói szerveződések, (2) mitől függ, hogy két cég kapcsolatában betölt-e szerződéstámogató funkciót a vállalkozói szerveződés?

Kiindulópontja az, hogy a tranzakciók jellemzői magyarázzák a kapcsolat alapvető „irányítási struktúráját”, amelyben a felek a megállapodásaikat megkötik és megvalósítják (Williamson, 1979). Az irányítási struktúra mindig a különféle intézményi mechanizmusok valamilyen koherens egésze, és a vállalkozói szerveződéseknek ebbe kell illeszkedniük. A vállalkozói szerveződésekre a célorientált üzleti hálózatokat irányító szervezetekként tekint, amelyek a spontán és az állami rend intézményei között helyezkednek el, így elsősorban azok korlátai magyarázzák helyettesítő és kiegészítő szerepüket. Sejtései szerint információközvetítő és szakmai-etikai ellenőrző funkciókat töltenek be, kiegészítve koordinációs és kikényszerítési mechanizmusokkal.

Az esettanulmány alátámasztja a sejtéseket, a következő összefüggéseket feltárva: (1) a vállalkozói szerveződésekre hagyatkozás és az üzleti kapcsolatok hosszú távú, relációs jellege, illetve a partnerek integrációjának mértéke között átváltás van, (2) a vállalkozói szerveződésekre hagyatkozás és az üzletfelek piaci reputációja között részleges átváltás van, (3) piaci közvetítők alkalmazása növelheti és csökkentheti is a vállalkozói szerveződések szerepét, (4) az állami rend jelentősége növelheti a vállalkozói szerveződésekre való hagyatkozást.

Kulcsszavak: vállalkozói szerveződések, szerződéses kapcsolatok, üzleti hálózatok, irányítási struktúra, vetőmagszektor

How do business associations support interfirm contractual relations? The author seeks to answer two questions: (1) what contract supporting functions do business associations fulfil?, (2) what explains whether business associations play a supporting role in a contractual relationship? He studies the case of a Hungarian industry based on fieldwork in the regions of Central Hungary and Central Transdanubia.

His starting point is that transactional features explain the basic governance structure which partners utilize to carry out contracts (Williamson, 1979). These are more-or-less coherent combinations of institutional mechanisms, into which business associations need to fit. He conceptualizes business associations as network administrative organizations in-between spontaneous and public order institutions, expecting the limitations of those institutional alternatives to explain associations' roles in the governance structure. He conjectures that they institutionalize information-sharing and professional-ethical control, supplemented by coordination and sanctioning mechanisms.

The case study supports his conjectures, uncovering the following relationships: (1) reliance on business associations and long-term relational contracts or integration are substitutes, (2) reliance on business associations is partially substituted by market reputation, (3) the use of market intermediaries can increase or decrease reliance on business associations, (4) reliance on public order mechanisms is complemented by reliance on business associations.

Keywords: business associations, contract enforcement, network administrative organizations, governance structure, seed industry

Finanszírozó/Funding:

A kiadvány/publikáció a Széchenyi 2020 program EFOP-3.6.1-16-2016-00013 "Intelligens szakosodást szolgáló intézményi fejlesztések a Budapesti Corvinus Egyetem székesfehérvári Campusán" című európai uniós projektje keretében készült.

\section{Szerző/Author:}

Molnár Gábor Tamás, PhD-hallgató, Budapesti Corvinus Egyetem (gabortamas.molnar@uni-corvinus.hu)

A cikk beérkezett: 2019. 05. 16-án, javítva: 2019. 07. 29-én, elfogadva: 2019. 08. 07-én.

This article was received: 16.05.2019, corrected: 29.07.2019, accepted: 07.08.2019. 
$\mathrm{H}_{\mathrm{a}}^{\circ}$ ogyan támogatják az ágazati-szakmai szerveződések a vállalkozások közötti szerződéses kapcsolatokat? Minden üzleti kapcsolat azon alapul, hogy a felek (többékevésbé) hitelesnek fogadják el egymást, és arra számítanak, hogy betartják a megállapodásokat. Az intézményi közgazdaságtan hangsúlyozza, hogy a hitelességet különféle, a szerződések betartatását kikényszerítő intézmények teremthetik meg: olyan társadalmi játékszabályok, amelyek szankcionálják az ígéretszegést (Greif, 2002; North, 1990). Az egyik legfontosabb stratégiai menedzseri döntés az üzleti kapcsolat megfelelő beágyazása ilyen játékszabályokba (Poppo \& Zenger, 2002; Williamson, 1979). De fontos e döntések megértése a szakmai politikai döntéshozók számára is, a vállalkozások közötti kapcsolatokat támogató intézmények megítéléséhez. A nemzetközi és hazai szakirodalomban egyre több empirikus bizonyíték szól amellett, hogy e rend fontos elemeit képezik az üzleti vállalkozások által létrehozott szakmai, ágazati vagy közös érdekeiket más módon segítő formális szervezetek röviden vállalkozói szerveződések (business associations) (Prüfer, 2016, p. 306). A hosszú távú relációk, társadalmi normák és reputációs mechanizmusok spontán, informális szabályai és a formális állami jogrend korlátai nyomán kialakuló intézményi keresletre jelenthetnek választ. Az elöbbiekkel szemben formálisak, tudatosan tervezettek, így képesek meghaladni azok földrajzi és közösségi korlátait. Az utóbbitól eltérően alapvetően magánintézmények (Greif, 2008), így kevésbé költségesen vehetők igénybe, és rugalmasabban képesek alkalmazkodni tagjaik igényeihez. A tervezett magánrend elemei között úgy tudjuk elhelyezni a vállalkozói szerveződéseket, hogy az üzleti hálózatok irányítási struktúrájának elemeinek tekintjük őket. A vállalkozói szerveződésekre úgy tekinthetünk, mint a célorientált üzleti hálózatokat irányító szervezetekre (Provan \& Kenis, 2008), szembeállítva őket a más irányítási struktúrákon keresztül müködtetett hálózatokhoz kapcsolódó intézményekkel ${ }^{1}$.

A vállalkozói szerveződések elvileg sokféle módon hozzájárulhatnak a szerződéses ígéretek hitelessé tételéhez. Támogathatják az információk áramlását a cégek üzleti tevékenységéről, megbízhatóságáról, folytathatnak etikai vagy szakmai szempontú ellenörzést, segíthetik a viták rendezését. Egy kis- és közepes vállalati felmérés (Mike, Boza, \& Molnár, 2018), valamint egy értékalapú vállalkozói klubban részt vevő cégeket vizsgáló esettanulmány (Mike, 2018) megerősíti, hogy a vállalkozói szerveződések folytatnak ilyen irányú tevékenységeket a magyar gazdaságban.

De az eddigi empirikus vizsgálatok jelzik azt is, hogy korántsem minden vállalkozás, minden üzleti kapcsolat számára fontosak a vállalkozói szerveződések. Nagyon keveset tudunk arról, mitől függ, hogy két cég szán-e a kapcsolatában szerepet ennek az intézményi megoldásnak. A másik oldalról korántsem minden szerveződés ugyanazokat a funkciókat tölti be. A tanulmányom célja, hogy többet tudjunk meg e két kérdésről, s ezzel mélyebben megértsük a vállalkozói szerveződések piacgazdaságban betöltött szerepét.

Egy magyar ágazatról készített, a Közép-dunántúli és Közép-magyarországi régióban végzett terepmunkán alapuló esettanulmány segítségével keresek magyarázatot arra, hogy (1) milyen szerzödéstámogató funkciókat töltenek be a vállalkozói szervezödések egy ágazat müködésében, továbbá (2) milyen tényezők befolyásolják, hogy két cég kapcsolatában betölt-e szerződéstámogató funkciót vállalkozói szervezödés. A vizsgált ágazat a vetőmagszektor. Olyan ágazatról van szó, amelyben sokféle szereplő és sokfajta üzleti kapcsolattípus létezik egymás mellett, és egy jelentős, nagy hagyományú, valamint több kisebb szakmai-ágazati szerveződés is kialakult.

Az esettanulmány célja - egy fontos hazai ágazat müködésének jobb megértésen túl - az elméletépítés. A szakirodalom alapján csak sejtéseink vannak a kérdéseinkre adható válaszokról. Az elemzés célja e sejtések nyomán pontosabb elméleti összefüggések megfogalmazása, amelyek a későbbiekben további eseteken és nagyobb mintán hipotézisekként tesztelhetők. A kutatási kérdések megválaszolása közelebb visz minket annak megértéséhez, hogy miként egészítik ki (illetve helyettesítik) a vállalkozói szerveződések az irányítási struktúrákban szereplő magán- és állami alternatíváikat. Ez megalapozhatja a vállalkozói szerveződések kialakulásának és intézményesülésének funkcionális magyarázatát, mivel a szerződéses kapcsolatok támogatása a szerveződések egyik alapvető funkciója.

Ami a vállalati döntéseket illeti, sejtéseim szerint alapvetően a tranzakciós költségek közgazdaságtanával magyarázható, hogy egy üzleti kapcsolatban megjelenike valamely vállalkozói szerveződés szerződések betartatását kikényszerítő támogató intézményként, s ha igen, akkor milyen formában. Eszerint a tranzakciók jellemzői (ismétlödése, a felek meglévő kapcsolata, valamint a jószágok komplexitása, mérhetősége, egyedisége) magyarázzák a kapcsolat alapvető „,irányítási struktúráját”, vagyis azt az intézményi keretet, amelyben a felek a megállapodásaikat megkötik és megvalósítják (Williamson, 1979). A választott irányítási struktúra mindig a különféle informális és formális intézményi mechanizmusok valamilyen koherens egésze (Mike \& Kiss, 2018; Williamson, 1979), nem pedig tetszőleges keveréke. Így a vállalkozói szerveződéshez kapcsolódó mechanizmusoknak is ebbe kell illeszkedniük. Feltevésem szerint tehát alapvetően a szerződést jellemző irányítási struktúrától függ, hogy a szerződés kikényszerítésében mekkora és milyen szerepe van a vállalkozói szerveződéseknek. A funkcionalitás feltárását bonyolítja, hogy a válasz kétlépcsős: (1) a hálózati (közösségi) koordináció mechanizmusainak lehetnek elő-

\footnotetext{
${ }^{1}$ A vállalkozói szerveződések elkülönülnek a Ménard (2004, 2013) által felsorolt klasszikus hibrid intézményektől (joint ventures, strategic alliances, sports leagues, franchises, consortia), mert nem feltétlenül jelentenek közös beruházást, termelés koordinálását. Ménard (2013) ugyanakkor a hálózatokat is a hibridek közé sorolja, így a vállalkozói szerveződések mint a formális irányítási struktúrával rendelkező hálózatok központi intézményei ebben az értelemben hibrid intézmények.
} 
nyei a piaci és állami mechanizmusokhoz képest, valamint (2) a vállalkozói szerveződések elsődleges funkciójuk, a hálózati szintű koordináció sikeres intézményesülése mellett piaci és állami mechanizmusokat is kiegészíthetnek.

Általános feltevésem, hogy mivel a vállalkozói szerveződések a spontán és az állami rend intézményei között helyezkednek el, elsősorban azok korlátai magyarázzák a szerveződések lehetséges helyettesítő és kiegészítő szerepét. A hálózati irányítási struktúrák között megkülönböztető jellemzőjük az, hogy külön intézményesült központi szervezetet biztosítanak. Az ebből eredő előnyök jelentősége a meglévő kapcsolatok jellegétől, a szereplők számától és távolságától, valamint a bilaterális megoldások korlátaitól függ.

Az esettanulmány igazolja a sejtéseket, és a következő pontosabb összefüggéseket tárja fel:

1. A vállalkozói szerveződésekre hagyatkozás és az üzleti kapcsolatok hosszú távú, relációs jellege, illetve a partnerek integrációjának mértéke között átváltás van. A vállalkozói szerveződések szerződések betartását kikényszerítő támogató funkciói elsősorban a rövid távú, piaci jellegü kapcsolatokban fontosak.

2. A vállalkozói szerveződésekre hagyatkozás és az üzletfelek piaci reputációja között részleges átváltás van. A vállalkozói szerveződések információközvetítő funkciója támogathatja a reputáción alapuló kikényszerítést, viszont a szerveződések ellenőrzési és vitarendezési tevékenysége a reputációjukra kevésbé hagyatkozó cégeknél fontosabb.

3. A piaci közvetítők alkalmazása növelheti a vállalkozói szerveződések jelentőségét, amennyiben a közvetítők kapcsolataik kiépítésében hagyatkoznak a szerveződések funkcióira, másrészt csökkentheti, amennyiben a közvetítők kiterjesztik a szerveződések funkcióit kapcsolati és hírnévalapú szankciókkal helyettesítő irányítási struktúra terét.

4. Az állami rend mechanizmusainak fontossága növelheti a vállalkozói szerveződésekre való hagyatkozást, mivel a szerveződések csatornázzák be a vállalkozói közösségek szempontjait a kormányzathoz, megalapozva a formális állami mechanizmusok müködését.

\section{A vállalkozói szerveződések szerződéstámogató funkciói és a tranzakciós költségek csökkentése}

A szerződések kikényszerítését támogató intézmények két fö funkciót töltenek be: információt biztosítanak a szerződő felek tevékenységéről, ezzel megalapozva a szankcionálás mechanizmusait, illetve saját szankciókat intézményesítenek a kikényszerítés alátámasztására. A vállalkozói szerveződések esetén ez kiegészül egy szerződéstámogató funkcióval, amely a szerződések költségeit csökkenti a keretek koordinálásával.

\section{Információközvetítés}

Az információközvetités a partnerekröl egyrészt jelentheti a (1) potenciális partnerek megtalálásával járó keresési költségek csökkentését, másrészt a szerveződések (2) információt közvetíthetnek a potenciális partne- rek múltbeli magatartásáról. Az információ formája lehet maga a tagság ténye, a szerveződés által nyújtott minősítés, vagy a szerveződésen keresztül megosztott tapasztalatok. A vállalkozói szerveződésnek etikai és szakmai normákat kell megfogalmaznia, illetve közös hírnevet kell fenntartania (Tucker, 2008) ahhoz, hogy a tagság ténye hiteles információt közvetítsen. Az információközvetítő és szankcionálási tevékenység összefonódik, mivel a tagság vagy a kedvező minősítés megvonása már szankciót jelent a közvetített információn keresztül. A szerveződések (3) a szerződéses viták kivizsgálásán keresztül új információt is állíthatnak elö.

\section{Szankcionálás}

A szankcionálás támogatására (1) a szerveződések saját vitarendezési tevékenységet folytathatnak, ami kevésbé költséges lehet a felek számára, mint a formális jogi kikényszerítés. A vállalkozói szerveződések ezen kívül (2) szankcionálhatják saját tagjaikat. Intézményesíthetnek köztes szankciókat, mint a pozitív minősítés megvonása, a bírság és a felfüggesztés, de a végső garancia a nem megfelelő partnerek kizárása. Önkéntes szerveződésként ugyanis csak az általuk nyújtott szolgáltatások megvonásán keresztül ösztönözhetik a feleket a szankciók elfogadására, mérlegelésére. A vállalkozói szerveződések képesek lehetnek (3) a tagjaikon kívüli szereplőket is szankcionálni, azzal, hogy koordinálják kiközösítésüket, vagy ösztönzik tagjaikat a normasértők kizárására üzleti kapcsolataikból.

\section{Koordináció}

Az eddigieket kiegészíti a tranzakcióval kapcsolatos várakozások koordinálásának funkciója, amely a szerződéses keretek közös artikulálásán alapul. A vállalkozói szerveződések önszabályozása kiterjedhet a szerződéses kapcsolatok általános kereteire, ezzel csökkentve az alkudozással és a specifikálással járó tranzakciós költségeket (Macaulay, 1963). Ez lehet ajánlás, de jelenthet explicit korlátokat is a tagok szerződéses kapcsolataira vonatkozóan, szerződésmintákon, irányárakon, minőségi standardokon keresztül.

\section{Empirikus eredmények}

Mike, Boza és Molnár (2018) áttekintést ad az empirikus eredményekről, amelyek alátámasztják, hogy a vállalkozói szerveződések szerződéstámogató szerepe számos esetben releváns. A legtöbb eredménnyel az angolszász kontextusról rendelkezünk (Battisti \& Perry, 2015; Bennett, 1998; Bennett \& Ramsden, 2007; McCormick, Hawley, \& Meléndez, 2008; Perry, 2009), amelyek alapján a szerződéstámogató funkciók intézményesülnek, bár általában másodlagosak az érdekképviselet mellett. A posztszocialista (Broadman et al., 2004; Hendley, Murrell, \& Ryterman, 2000; Pyle, 2006) és a fejlődő országokban (Doner \& Schneider, 2000) kifejezetten jelentős a vállalkozói szerveződések szerződéstámogató szerepe. A tágabb intézményi kontextus hatással lehet: fejletlenebb intézményi rendekben fontosabb a szankcionáló és koordinatív funkció, míg fejlettebb kontextusokban az információmegosztás elsődleges. A szerződéses partnerek megbíz- 
hatóságára vonatkozó eredmények alátámasztják az információközvetítés funkció elsődleges szerepét (Pyle, 2005), míg a szankcionálás és koordináció kevésbé relevánsak. A magyarországi eredmények ebbe illeszkednek. Mike (2018) egy értékalapú vállalkozói szerveződés esetén, míg Mike, Boza és Molnár (2018) a magyar KKV-k kérdőíves felmérése alapján mutatja ki a vállalkozói szerveződések szerződéstámogató szerepét. Mindkét esetben az információközvetítés és az etikai szelekció tevékenységei voltak a legjelentősebbek.

\section{Vállalkozói szerveződések az irányítási struktúrákban}

Milyen cégek, milyen kapcsolatokban hagyatkoznak a vállalkozói szerveződések szerződéstámogató mechanizmusaira? Ez nem elszigetelt döntés, mivel a felek tranzakcióik során többé-kevésbé koherens irányítási struktúrákat alakítanak ki (Williamson, 1979), amelyeknek illeszkedniük kell a tranzakciókhoz. E struktúrák elemeit az intézményesülésük (magán vagy állami) és a formalizáltságuk alapján (spontán vagy tervezett) csoportosíthatjuk. A spontán rend körébe tartoznak az erkölcsre, a szerződéses szankciók önkikényszerítő jellegére, a jövőbeli partnerek szankcióin alapuló hírnévre, illetve a normák közösségi kikényszerítésére hagyatkozó mechanizmusok. Ezeket támogathatják meg az állami rend formális szankciói.

A vállalkozói szerveződések a tervezett magánrend elemeiként a spontán és a tervezett állami rend között helyezkednek el (Mike et al., 2018). A szerveződések létrehozása, fenntartása és igénybevétele költséges (Mike, 2018, p. 5), vagyis várhatóan olyan üzleti kapcsolatok esetén van rájuk igény, ahol a magán- és állami rend alternatív mechanizmusai korlátozottan felelnek meg a tranzakció igényeinek. A tervezett magánrend körébe sorolható intézmények ugyanakkor a vállalkozói szerveződések helyettesítői lehetnek. Ezek vagy a hierarchikus koordináció magánintézményei, mint az integrációs és kvázi-integrációs vállalati formák, vagy a spontán rendet kiegészítő, minősítő, információszolgáltató, szabványosító, kikényszerítést kínáló vállalkozások.

\section{Vállalkozói szerveződések mint hálózatot irányító szervezetek}

A vállalkozói szerveződések és az alternatív intézményi mechanizmusok közötti kapcsolatokhoz az iparági közösséget üzleti hálózatként konceptualizálva kerülhetünk közelebb. A szereplök hálózatok mentén szervezik meg a tranzakcióikat, az iparági közjószágok (tudásmegosztás, kedvező szabályozás) előállítását, valamint a szerződéskikényszerítés közösségi mechanizmusait (hírnév, szakmai normák, formális szankciók). Ezeknek a hálózatoknak három fö típusát különböztethetjük meg (Provan \& Kenis, 2008). Az első típus a vállalatokon, üzleti csoportokon belüli szereplökből formálódó, belső hálózatok (Borbély, 2001). A hálózatok szűkebb definíciói ezeket nem tekintik valódi üzleti hálózatnak (Besser \& Miller, 2011; Provan \& Kenis, 2008), ugyanakkor számottevő irodalom közelíti meg a nemzetközi vállalatok kormányzását hálózatként (Ghoshal \& Bartlett, 1990; Harzing, 1999). A több, önálló szervezetből álló üzleti hálózatok két csoportja a spontán kialakult (serendipitous) és a célorientált (goal-directed) hálózatok. Az előbbiek a személyes ismeretségek és kétoldalú üzleti kapcsolatok eredményeként állnak össze, így a spontán rend mechanizmusaihoz köthetők. A célorientált hálózatok intézményesült irányítási struktúrával (network governance structure) rendelkeznek. Bár ez a struktúra építhet az állami rendre is, az üzleti hálózatok a tervezett magánrend intézményeihez kapcsolhatók, mert magánszereplők részvételén alapulnak.

Az irányítási struktúrával rendelkező, célorientált üzleti hálózatok három fajtáját különböztethetjük meg (Provan \& Kenis, 2008). Közös irányitás (shared governance) esetén az irányítás nem egy kijelölt szervezet feladata, hanem a szereplők közösen végzik el. Az ilyen irányítású hálózatokban minden szereplő majdnem minden szereplővel kapcsolatban kell, hogy álljon. A vezetö szervezeten alapuló hálózatok esetén egy központi szereplő magára veszi az irányítás feladatait. Ekkor a hálózatot a vele való kétoldali kapcsolatok strukturálják, a többi szereplőnek nem szükséges közvetlen kapcsolatban állnia. A harmadik esetben a szereplők közösen intézményesítenek egy önálló, a hálózatot irányító szervezetet (network administrative organization). Üzleti hálózatok esetén ezek a szervezetek a vállalkozói szerveződéseknek felelnek meg: formális, tervezett nonprofit magánintézmények, amelyek az üzleti hálózat tagjainak érdekeit hivatottak elömozdítani. Ebből következik, hogy az üzleti hálózati formák irányítására és a vállalkozói szerveződések szerepére vonatkozó tudásunk összekapcsolható. A vállalkozói szerveződések és intézményi alternatíváik közötti kapcsolatok megfeleltethetők az irányítást szervezeteken (vállalkozói szerveződéseken) keresztül megvalósító és a más irányítási formákra hagyatkozó célorientált üzleti hálózatok közötti kapcsolatoknak. Az 1. táblázat áttekintést ad az üzleti hálózatok főbb formáiról és a hozzájuk kapcsolódó irányítás intézményi formáiról.

1. táblázat Az üzleti hálózatok típusai és a kapcsolódó intézmények

\begin{tabular}{|c|c|}
\hline Üzleti hálózati forma & Irányitás intézményi formái \\
\hline 1. Spontán kialakuló (informális) hálózatok & Spontán rend intézményei \\
\hline 2. Irányított, célorientált hálózatok & Tervezett magánrend intézményei \\
\hline a) Belső (szervezeten belüli) hálózatok & Vállalati hierarchiák, vállalatcsoportok \\
\hline b) Közös irányítású szervezetközi hálózatok & Stratégiai partnerségek, vállalatközi projektek \\
\hline c) Vezető szervezeten alapuló szervezetközi hálózatok & Kvázi-integráció, közvetítők és integrátorok \\
\hline d) Szervezeti irányításon alapuló szervezetközi hálózatok & Vállalkozói szerveződések \\
\hline
\end{tabular}

Forrás: saját szerkesztés Provan \& Kenis (2008) nyomán 


\section{Kapcsolat a spontán renddel}

Ott számíthatunk a vállalkozói szerveződések jelentősebb szerepére, ahol a spontán rend korlátai jelentősek, így jobban igénylik a helyettesítést vagy kiegészítést. (1) A spontán kialakuló személyes és szakmai hálózatok ritkább jellege esetén, valamint (2) a piacon kevésbé ismert (újabb, kisebb) vállalkozások szerződésében az erkölcs, normák és hírnév kevésbé tudnak érvényesülni. (3) Rövidebb előzményü és kisebb eséllyel folytatódó szerződések, valamint (4) nehezen specifikálható szerződéses elemek esetén az önkikényszerítés hatásossága korlátozott. A termékjellemzők a reputációs mechanizmusokat is korlátozhatják, így (5) minél nehezebben definiálhatók és kommunikálhatók a fogyasztók felé a termékminőség paraméterei, annál jobban megéri a szereplőknek közösen garantálni azt (Gehrig \& Jost, 1995).

(6) A partnerek földrajzi távolsága kétféleképpen függhet össze a mechanizmusok kiválasztásával. Amikor mindkét elismeri a vállalkozói közösség hitelességét, akkor minél távolabbiak, minél kevésbé tudnak az informális kapcsolatra hagyatkozni, annál nagyobb a vállalkozói szerveződés mechanizmusainak jelentősége. Egy adott távolságon túl azonban a vállalkozói szerveződések nem relevánsak, míg az önkikényszerítésen és hírnéven alapuló mechanizmusok lehetnek azok. A nagyobb kapcsolati távolság a posztszocialista kontextusokban (Pyle, 2005, 2006) és konkrétan a magyar esetben is a vállalkozói szerveződések jelentősebb szerepével jár együtt (Mike et al., 2018).

\section{Kapcsolat az állami intézményekkel}

A vállalkozói szerveződések erősebb szerepére ott számíthatunk, ahol az állami rend korlátai jelentősebbek. Kevésbé hagyatkoznak a felek az állami kikényszerítésre, (1) ahol költséges a hozzáférés, vagy az eredmény nem megbízható. Az állami mechanizmusok megbízhatatlansága annál költségesebb, minél kritikusabb a tranzakció és a rendezés időzítése. (2) Ahol olyan specifikus szerződéses elemek vannak, amelyekre az állami kikényszerítés nincs megfelelően tekintettel, ott kevésbé hagyatkoznak rá. Ilyen a specifikus, a szakmai tudáselemek, gyorsan változó, nehezen specifikálható jószágok és kooperációs formák jelenléte. A szerveződések előnyei annál jelentősebbek, minél nagyobb információs költségekkel szembesülne a kormányzati szabályozó a tevékenység innovatív jellegéből és technológiai egyediségéből adódóan. A kiterjedt, vállalkozói szerveződéseket is tartalmazó magánrendre hagyatkozó iparági közösségek általában ilyen, specifikus szerződéses elemeket próbáltak kikényszeríteni, (Bernstein, 1992, 2001). Az állami müködés nyilvánossága is korlátozhatja szerepét. (4) Ha a felek üzleti titok, vagy hírnév okán a nem nyilvános megoldásokat preferálják, akkor inkább a magánrendre hagyatkoznak.

\section{Kapcsolat a tervezett magánrenddel}

A vállalkozói szerveződések jelentősebb szerepére olyan esetekben számíthatunk, ahol a tervezett magánrendi alternatívák korlátai jelentősebbek. A közös irányítás esetén nincs központi szereplő, míg az integráció, kvázi-integráció és a közvetítők esetén a központi szereplő egy profitorientált vállalkozás ${ }^{2}$. A vállalkozói szerveződések jellemzője, hogy a központi szereplő egy közösen intézményesített szervezet. Ennek előnye, hogy nem szükséges hozzá minden fél által elfogadott központi piaci szereplő, ami leginkább akkor releváns, (1) ha az ügyletek rövidebb távon, váltakozó partnerek között valósulnak meg. A vállalkozói szerveződéseken alapuló üzleti hálózati irányítás előnyei akkor a legjelentősebbek, amikor (2) a résztvevők közötti bizalom egyenletesen oszlik el és közepes mértékü, (3) a kapcsolatok nagyobb számú, változó felek között jönnek létre, valamint (4) szükség van a közösségi szintű mechanizmusok működtetésére a szerződéses kapcsolatokhoz (Provan \& Kenis, 2008). A spontán rendet kiegészítő szabványok és minősítők ott érhetők el kevésbé, (5) ahol nehezen specifikálható jellemzők vagy üzleti titkok vannak; vagyis az állami rendhez hasonló korlátokkal szembesülnek.

\section{Irányítási struktúrák és vállalkozói szerveződések}

Hogyan illeszkednek a vállalkozói szerveződések a szerződéskikényszerítés irányítási struktúrájába? A megfigyelt intézményi kombinációk alapján fogalmazhatunk meg további sejtéseket.

(1) Az állami intézmények információs, szakmai és procedurális hiányosságai esetén a vállalkozói szervezödések vehetik át a szerepüket a spontán rend kiegészitésében (Johnson, McMillan, \& Woodruff, 2002; Nugent \& Sukiassyan, 2009). Ez egyfajta tervezett magánintézményekkel megtámogatott, bilaterális és hírnévalapú irányítási struktúrát eredményez (Francis, Karalashvili, \& Murrell, 2018; Hendley \& Murrell, 2003) A magánrendre való hagyatkozás kiugró esetei azon iparági közösségek, amelyekben az erős informális rend és a vállalkozói szerveződések tevékenységei helyettesítik az állami rendet (Bernstein, 1992, 2001).

(2) Ha a magán-és az állami intézmények müködnek, de kiegészitésre szorulnak, akkor egy átfogó, sokféle intézményre hagyatkozó irányítási struktúra elemei lehetnek a vállalkozói szervezödések (Lane \& Bachmann, 1997; Murrell, 2003). Minél nagyobb az opportunizmus kockázata a kapcsolati és jószágjellemzőkön keresztül, annál valószínủbb, hogy a felek átfogó irányítási struktúrára hagyatkoznak (Lazzarini, 2004; Mike \& Kiss, 2018), amelyekben a vállalkozói szerveződések is szerepet kapnak.

(3) Sajátosan posztszocialista eset, amikor a vállalkozói szervezödések állami kapcsolati hálóra épülnek rá, helyettesítve a magánrendet (Hendley et al., 2000).

A vállalkozói szerveződések szerepét magyarázhatják intézményesülésük körülményei. Ha a magán- vagy az állami rend nagyon gyenge, akkor azt inkább helyettesítik a vállalkozói szerveződések, amennyiben képesek a másikra támaszkodva intézményesülni. Ha mindkét rend fejlett, akkor a vállalkozói szerveződések mindkettőt kiegészítve intézményesülnek.

\footnotetext{
${ }^{2}$ A közvetítő vállalatok szerepéről a piacok megszervezésében és a tranzakciós költségek csökkentésében lásd Spulber (1999) munkásságát.
} 


\section{Esetválasztás és módszertan}

Az empirikus kutatásunk feltáró jellegü, elméletépítő esettanulmány (Eisenhardt, 1989). A célunk nem hipotézisek tesztelése, hanem az előző részben szemlézett tényezők és interakcióik sokaságának megfigyelése egy eset mélyreható vizsgálatával. Ez megalapozza a pontosabb összefüggések és a későbbi nagymintás vizsgálatok tárgyát képező hipotézisek megfogalmazását.

\section{Esetválasztás}

Az országos ágazatok közül választottam esetet, mert a tranzakciós kihívások tipikus formái, valamint a szabályozási környezet feltételezhetően ilyen kiterjedésủ vállalkozói közösségek esetén a leginkább hasonló. Fő szempontjaim az intézményi kereslet és kínálat tényezői voltak: olyan esetet kerestem, ahol jelentős tranzakciós problémákra adott egy közösség intézményi megoldásokat. Választott esetem a magyarországi vetőmagszektor, amely kiemelten jelentős tranzakciós problémákkal szembesült, ugyanakkor komoly informális és formális intézményi hagyományokra tudott támaszkodni ezek megoldásában. Ez a konfiguráció valószínüsíti a vállalkozói szerveződések fontos, ugyanakkor más intézményi mechanizmusokhoz kapcsolódó szerepét a szerződéstámogatásban ${ }^{3}$.

A vetőmag magas technológiaigényü, precizitást igénylö, tapasztalati jószág, így a bizalom mind az előállítása, mind az értékesítése során fontos tényezőként jelenik meg. A vetőmag és tágabban a mezőgazdasági input ágazat esetén az empirikus kutatások kiemelten fontos kérdésként azonosították a bizalom kérdését, ugyanakkor az irányítási struktúra számos elemét, köztük a vállalkozói szerveződéseket tárták fel, mint ezekre adott intézményi válaszokat. Nemzetközi kutatások elsősorban a hírnév és a hosszú távú partnerségen alapuló kétoldali kikényszerítés szerepét találták jelentősnek a szerződéskikényszerítésben (Burer, Jones, \& Lowe, 2008; Kumar \& Ali, 2010). Az állami intézmények hagyományosan domináns szerepe az ágazatban a nemesítői jogok kikényszerítését és a minőségi szabályozást egyaránt megalapozó regisztrációs rendszer müködtetése (Ghijsen, 2002; Louwaars, 2002a, 2002b). A nemesítöi tulajdonjogok szerződéses kikényszerítésében az állam mellett a második fél általi kikényszerítés, vagyis a nemesítö-eladó fél által a szerződésbe beépített szankciók és saját ellenőrzés mindenhol jelen van, de annál fontosabb, minél kevésbé hagyatkozhat az eladó a formális jogrendszerre (Monteiro \& Zylbersztajn, 2015). $\mathrm{Az}$ állami beavatkozás világszerte elterjedt, de a limitált kormányzati kapacitással rendelkező országok esetén a hírnéven alapuló mechanizmusok is képesek megalapozni a bizalmat (van Gastel, Gregg, \& Asiedu, 2002). A vállalkozói szerveződések a minőségi szabályozásban kapnak szerepet (van der Meer, 2002). A nemzetközi vállalkozói szerveződések növekvő szerepet töltenek be a minőség állami és önszabályozásban (Buanec \& Heffer, 2002). A nemzetközi vetőmag-kereskedelem önszabályozása ezen túlmutat, mivel a szerződéses keretek koordinációja és a vitarendezés a Nemzetközi Vetőmag Szövetségi keretei között zajlik (Buanec, 2002).

A magyar vetőmagszektor intézményi hagyományai a XIX. századig nyúlnak vissza, és a XX. század viszontagságait is sikerrel vészelték át, különleges szerepet betöltve a szocialista gazdasági rendszerben (Izsáki \& Lázár, 2004). A vetőmagszektor az állami és a magánrenddel együttműködve fejlődött, és több ágazati szerveződés is kialakult. A rendszerváltás óta komoly kihívásokkal szembesült az ágazat a gazdasági átmenettel járó átstrukturálás, majd a nemzetközi versenytársak belépése nyomán. A magyar vetőmagszektor sikeresen vette az akadályokat: integrálódott a globális láncokba, és kifejezetten exportképes (International Seed Federation, 2016).

A bizalom és a szerződéskikényszerítés a magyar agrárágazat számára is kulcskérdés (Fertő, 2012b). Az ágazat egyik fő problémája, hogy a szétaprózott magyar termelői közösség tagjai miként tudnak bekapcsolódni a globális értékláncokba, hogyan tudnak versenyképesek lenni a nemzetközi nagyvállalatokkal (Fertő \& Bakucs, 2012a).

A szerződéses kapcsolatokban megnyilvánuló bizalom és a szerződéskikényszerítés irányítási struktúrája kapcsán vannak eredmények a magyar agrárszektorra vonatkozóan. A részletes, írásos szerződések jelentősége növekvő (Fertő, 2012a), viszont a szerződések jogi kikényszerítése lassú és költséges (Fertő \& Bakucs, 2012b). Ez arra utalhat, hogy a szerződéses kapcsolatok sikeres megvalósítása komoly költségeket ró a szereplökre.

A magyar agrárágazat együttmüködési megoldásairól, köztük a kutatásunk tárgyát képző szakmai és szakmaközi szervezetekről áttekintést adnak Biró és szerzőtársai (2015). Általános tapasztalat, hogy az együttműködés jelenti az agrárgazdasági szereplők versenyképességének alapját. A legtöbbet kutatott intézmények a szövetkezetek és egyéb termelői együttműködési formák (Bakucs, Fertő, \& Szabó, 2012; Szabó, 2010), amelyek nagyrészt erötlenek az érdekképviseletet és a szerződéses keretek befolyásolását tekintve (Szabó \& Baranyai, 2017).

\section{Módszertan}

Az eset előzetes dokumentumelemzéses feldolgozása a releváns szereplők, intézmények és kollektív kihívások azonosításával alapozta meg az interjúfonalat és a mintavételt. A terepmunka során 2018. február és június között tizenkilenc, az ágazat müködtetésében részt vevő vállalkozóval és szervezetvezetővel folytattam félig-strukturált interjút. Az interjúk négy kérdésre fókuszáltak. (1) Az adott szervezet tevékenységének és szerződéses kapcsolatainak leírása. (2) Az ágazat fö kihívásai és (3) az azokra adott intézményi válaszok sikeressége. (4) A vállalkozói szerveződések szerepe a szerződéses kapcsolatok működésében.

\footnotetext{
${ }^{3}$ A kutatás céljai között szerepelt az intézményi forma és a szerződéstámogató funkció betöltése közötti összefüggések feltárása is. Az eset feltárása során kiderült, hogy a szerveződések funkcionalitása olyan nagymértékben koncentrálódik egyetlen szervezet (a VSZT) köré, hogy ezt a kutatási ambíciót fel kellett adnom
} 
Mivel a kutatás nem hipotézistesztelö, hanem elméletépítő jellegü, az interjúalanyok kiválasztása elméletvezérelt mintavétellel történt (Eisenhardt \& Graebner, 2007) ${ }^{4}$. A mintavételnek három fö szempontja volt: (1) a legfontosabb szereplők megkérdezése, (2) a szegmensek (kalászos, hibrid, zöldség) és szakmák (nemesítő, fajtatulajdonos, termelö, kereskedő-integrátor) egyedi szempontjainak feltárása, (3) a regionális tényezők jelentőségének feltárása. Az interjúk a nagyvállalatok számára elsődleges Közép-magyarországi régió mellett a Közép-dunántúli régióra koncentráltak, ahol jelentős hagyománya van a vetőmagszektornak. Ez lehetővé tette a helyi hálózatok hatásának feltárását.

\section{A magyar vetómagszektor esete}

\section{Összetett, bizalmi termék}

Képzeljünk el egy olyan világot, ahol a nyomtatás és digitalizáció nem elérhető, így a szövegeket csak fizikai hordozón lehet tárolni, amelyek gyorsan fakulnak, így az információ fenntartása folyamatos másolást igényel, ami erősen tökéletlen, így a tartalom nem marad változatlan. Ha ebben a világban a tanítás alapját a tankönyvek jelentenék, akkor ez a képzeletbeli tankönyvágazat jó párhuzamot jelentene a vetőmagágazat megértéséhez. A vetőmag értékét a tankönyvhöz hasonlóan a benne foglalt információnak és az azt fizikailag hordozó vetőmagnak (könyvnek) a környezet és a felhasználó igényeinek való megfelelősége adja meg. A hordozó minőségét költségesen fel lehet deríteni a tranzakciók során a fizikai paraméterek mérésével, viszont az információs tartalom minőségét csak a használat során lehet megállapítani, vagyis a vetőmag (tankönyv) tapasztalati jószág.

A vetőmagot a vetőmagipar kiépülése előtt a gazdálkodók állították elő maguknak, illetve egymásnak. E rendszernek a tapasztalati jellegnél is fontosabb korlátja az, hogy ha a növények szabadon továbbszaporíthatók, akkor a nemesítők alulösztönzöttek az új genetikai anyag elöállítására. További kihívást jelent, hogy a társadalom felügyelni akarja a forgalomba kerülő növényeket, hogy elkerülje az ökológiai katasztrófákat. Az intellektuális tulajdonjogok definiálása és állami elismerése ezekre ad megoldást. A vetőmagok esetén a növényfajta-oltalom definiálja a fajtatulajdonos kizárólagos, átruházható jogosultságát a fajta szaporítására, adaptálására, import-exportjára, értékesítésére, illetve ezekhez kapcsolódó tárolására. ${ }^{\text {ii }}$ A vetőmagágazat esetén a közgazdasági kulcskérdések, hogy (1) miként jut el a gazdához megfelelő információ megfelelő formában, (2) hogyan kompenzálják az információt létrehozó nemesítőt, hogy ösztönözve legyen az alkotásra, valamint (3) hogyan kompenzálják a vetőmagtermelőket, hogy a megfelelő mennyiségü és minőségü vetőmag előállítására legyenek ösztönözve.

\section{Folyamatok és szereplök}

A vetőmag előállításában öt fő lépés követi egymást, amelyeket kiegészíthet az informális vetőmagszektorhoz kapcsolódó három lépés (2. táblázat).

2. táblázat A vetőmagágazat folyamatai

\begin{tabular}{|l|l|}
\hline \multicolumn{1}{|c|}{ Tevékenység } & \multicolumn{1}{c|}{ Eredmény } \\
\hline 1. Nemesítés & Szuperelit \\
\hline $\begin{array}{l}\text { 2. Genetikai anyag átadása, } \\
\text { fajtafenntartás }\end{array}$ & Elitmag \\
\hline 3. Szaporítás & $\begin{array}{l}\text { Másod/harmadfokú } \\
\text { vetömag }\end{array}$ \\
\hline $\begin{array}{l}\text { 4. Szelektálás, kezelés, } \\
\text { kiszerelés }\end{array}$ & Hitelesített vetőmag \\
\hline $\begin{array}{l}\text { 5. Értékesítés, logisztika } \\
\text { Vetőmag } \\
\text { fogyasztónál }\end{array}$ & $\begin{array}{l}\text { Visszatartott } \\
\text { vetőmag }\end{array}$ \\
\hline $\begin{array}{l}\text { 6. Továbbszaporítás } \\
\text { 7. Visszatartott vetőmag } \\
\text { szelektálása, kezelése, } \\
\text { kiszerelése }\end{array}$ & $\begin{array}{l}\text { Nem hitelesített } \\
\text { vetömag }\end{array}$ \\
\hline $\begin{array}{l}\text { 8. Visszatartott vetőmag } \\
\text { értékesítése }\end{array}$ & $\begin{array}{l}\text { Vetőmag } \\
\text { fogyasztónál }\end{array}$ \\
\hline
\end{tabular}

Forrás: saját szerkesztés

Az első fontos elem a nemesítő kompenzálása, amelyet hagyományosan állami támogatással valósítottak meg. Ekkor a nemesítő díjazásért cserében lemondott a jogosultságairól, az államilag regisztrált fajtákat pedig szabadon hozzáférhetővé tették az előállítók számára. Jelenleg két fö megoldás található: a nemesítő eladja a jogosultságokat egy fajtatulajdonosnak, vagy vállalkozáson belül átadja a fajtatulajdonosnak a genetikai anyagot, aki a szaporítás és értékesítés jogosultságait másoknak értékesíti. A fajtatulajdonos adott időtartamon keresztül jogosult licencdíjra a fajtáit szaporítóktól, ezután a genetikai anyag szabadon felhasználható.

\section{Tranzakciós modellek}

A vállalkozói szerveződések szerepének tisztázásához először át kell tekintenünk, hogy melyek azok a tipikus tranzakciós formák, amelyekre adott válaszokban a szerveződések megjelenhetnek. Az ágazatban három fö tranzakciós problémára kell választ adni. Az első a licencszerződés, amely részleges formában mindenképp megjelenik, ha a fajtatulajdonos és a vetőmag-felhasználó nem azonosak, mert ekkor utóbbinak meg kell szereznie a szaporításra vonatkozó jogosultságot a fajtatulajdonostól. Kiterjedhet ugyanakkor a köztes szaporítás és kiegészítő tevékenységeinek átadására is a nem végleges vetőmag (elitmag) átadásával. A végpont az értékesítési szerződés, amely során megtörténik a szaporítási jogosultság átadása a gazdának a vetőmagon keresztül. A kettő között megjelenhet a termeltetési szerződés, amellyel az értékesítő szereplő kiszervezi a szaporítást. A három tranzakció meg-

\footnotetext{
${ }^{4}$ Az elméletvezérelt mintavétel során a feltételezett tényezők és az azok közötti lehetséges összefüggések szempontjából releváns, azokat reprezentáló eseteket választják ki, nem pedig a sokaság egy véletlen, statisztikailag reprezentatív részhalmazát.
} 
szervezésére három modellt azonosíthatunk, az informális vetőmagszektorral kiegészítve (1. ábra).

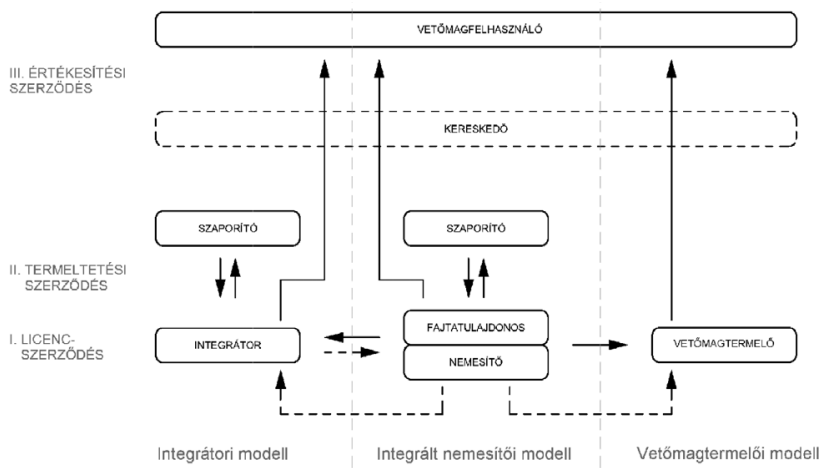

Vetőmagtermelöi modell

A fajtatulajdonos (I.) eladja egy vetőmagtermelőnek a szaporítás, feldolgozás és forgalomba hozatal jogosultságait elitmag formájában. A vetőmagtermelő (II.) hierarchián belül megszervezi a szaporítást és a kapcsolódó lépéseket, majd (III.) értékesíti a vetőmagot közvetlenül vagy kereskedőn keresztül.

\section{Integrátori modell}

A fajtatulajdonos (I.) eladja egy integrátornak a szaporítás, feldolgozás és forgalomba hozatal jogosultságait az elitmaggal együtt. A folyamat központi szereplője innentől az integrátor, aki a szaporítást és a kapcsolódó folyamatok egy részét (II.) kiszervezi termeltetési szerződéses partnereinek, majd (III.) értékesíti a vetőmagot közvetlenül vagy kereskedőn keresztül.

\section{Integrált nemesítői modell}

A fajtatulajdonos (I.) megtartja a jogosultságokat hierarchián belül, és (II.) maga szervezi ki a szaporítást közvetlenül vagy integrátoron keresztül. A szaporítás utáni feldolgozást általában maga végzi, majd (III.) értékesíti a vetőmagot közvetlenül vagy kereskedőn keresztül.

\section{Az informális vetömagszektor}

A megvásárolt vetőmagot a felhasználó továbbszaporítja, illetve a terményből visszatartja a vetőmagnak alkalmas szemeket. Az így kapott vetőmagot kezeli, majd saját maga visszaveti, vagy értékesíti.

\section{Szerződések irányítási struktúrái}

Milyen fő tranzakciós problémák merülnek fel az azonosított szerződéses kapcsolatok esetén, és milyen irányítási struktúrák alakultak ki azok megoldására?

\section{Lincencszerzödés}

A licencszerződés a fajtatulajdonos és az integrátor vagy vetőmagtermelő között jön létre, ahol az előbbi átadja a szaporításra és forgalmazásra vonatkozó jogosultságokat elit vagy szuperelit mag formájában. A licencet megvásárló félnek a genetikai anyag és az elitmag minőségében kell megbíznia, míg a fajtatulajdonosnak abban, hogy a másik megfizeti licencdíját. Ennek direkt eleme az elitmag ára, indirekt eleme pedig arra vonatkozik, hogy a szaporítás keretek között marad, nem rontja a piaci pozícióját, valamint behajtható marad a licencdíj a továbbszaporítóktól.

Az integrált nemesítői modellben ennek a tranzakciónak a szerepét a vállalaton belüli bürokratikus koordináció veszi át. Ezek a vállalatok kiterjedt, sokszor globális belső hálózatokat alakítanak ki a méretgazdaságosság és a helyi sajátosságok kihasználására, ahol a horizontális és vertikális integráció együtt jár. Ezt a tranzakciós költségek elméletével összhangban az idioszinkratikus, hosszú távú K+F beruházások magyarázzák (Williamson, 1979).

Az integrátori és a termelői modellben egyaránt a kétoldali megoldások és a hírnév valamilyen kombinációjára hagyatkozik a licencszerződés. A bilaterális megoldások a hosszú távú partnerségek és személyes ismeretségek kialakításán, ennek hiányában pedig próbavetéseken és részletes szerződéseken alapulnak. A másik fő elem a fajtatulajdonos és a fajta mint márkanév hírneve, amelyet a regisztrált növények potenciálját nyilvánosan összevetö, ún. posztregisztrációs kísérletek támogatnak meg a genetikai minőségre vonatkozóan, illetve az elitmag állami hitelesítése és fémzárolása a hordozó minőségére vonatkozóan.

\section{Termeltetési szerződés}

A termeltetési szerződés során a termeltető fajtatulajdonos vagy integrátor a szaporítási jogosultságának gyakorlásával bízza meg a szaporítót, szállítva az elitmagot, majd vetőmagot átvéve. A termeltető itt egy megbízó-ügynök problémával szembesül (Jensen \& Meckling, 1976), amely során meg kell bíznia abban, hogy a folyamat végén kapott vetőmag megfelelő minőségü lesz, amely elsősorban a folyamatok és a technológia precíz betartásától függ. Emellett meg kell bíznia abban is, hogy a szaporító a megegyezésnek megfelelő mennyiségű vetőmagot tart vissza magának, nem rejti el vagy értékesíti informálisan munkája eredményét. A szaporítónak az elitmag minőségében, illetve a bizonytalanságokkal terhelt végeredmény méltányos megosztásában kell bíznia.

A termelői modellben ez a tranzakció nem jelenik meg, mert a termelő végzi a teljes folyamatot. Az integrátori és az integrált nemesítöi modellben egyaránt a kétoldali megoldások és a hírnév kombinációja az irányítás alapja. A komoly szaporítók köre mindenki számára ismert legalább regionálisan, a hírnév kiépítése így fontos számukra. Csatlakozni ehhez a körhöz a meglévő fogyasztói kapcsolatok elmélyítésével lehet, így a termeltetési kapcsolat hosszú távú partnerségen alapul, amelyben a termeltető tanácsadással és technológiával is támogatja a szaporítót. A termeltetési szerződés általában tartalmaz értékesítést is, amennyiben a szaporító visszatarthatja magának a vetőmag egy részét, ezzel biztosítva ösztönzöttségét. Az integrátori modellben ez fejlődik tovább egy kvázi-integrált, vezető szervezeten alapuló hálózati struktúrává, amelyben a cserék az értékesítésre, további inputokra és akár a terménykereskedelemre is kiterjednek.

A termeltetés gyakran helyi közösségekhez kötődik, így a moralitás és a közös normák kiegészítő szerepe itt 
a legjelentősebb. A szakmaiság szerepe nagyobb, mert a szereplők tudják, hogy egy komoly termelőt önmagában büszkeséggel tölt el a jó eredmény. A két fél bizalmát az állami garanciák és a szerződéses kikényszerítés együtt alapozzák meg. Az állami hitelesítés a fémzároláson keresztül kontrollálja az elitmagot és a vetőmagot egyaránt, mindkét felet védve. Ezt egészíti ki a folyamatokat hitelesítő szántóföldi szemle ${ }^{\mathrm{iii}}$. Az integrátorok és fajtatulajdonosok kvázi-hierarchikus viszonyban koordinálják a folyamatokat, részletes utasításokat adva a szaporítóknak. Ennek keretében saját, az állami minimumnál szigorúbb minőségellenőrzési rendszereket müködtetnek.

\section{Vetőmag-értékesités}

Az értékesítés során a vetőmag felhasználója beszerzi azt a szaporítás jogával együtt annak birtoklójától, aki lehet a fajtatulajdonos, egy integrátor, egy termelö vagy egy kereskedő, aki az előbbi három szereplőfajta valamelyikétől közvetíti. A felhasználónak a vetőmagminőség genetikai és technikai elemében egyaránt meg kell bíznia, míg az eladó számára az ár kifizetése mellett a szaporítás kontrollja lényeges.

Az értékesítési szerződés irányítási struktúrája mindig a bilaterális megoldások és a hírnév valamilyen kombinációján alapul. A gazdák lassan kiépülő bizalma elsődleges, ezt korábbi kapcsolat híján próbavetésekkel alapozzák meg. Minden értékesítő törekszik személyes, hosszú távú kapcsolatok kialakítására a jelentősebb felhasználókkal. A rossz terméknek vagy nem megfelelő teljesítésnek nagyon gyorsan híre megy, így a személyes ismeretség mellett a cégek és termékek hírnevét tekintik az értékesítők legfontosabb erőforrásuknak. Az állami regisztráció és a posztregisztrációs kísérletek információt közölnek a genetikai minőségről, de a vállalatok saját mércéi és ígéretei ezeknél sokkal fontosabbak. A közvetítő kereskedők ezeket a mechanizmusokat támogatják azzal, hogy saját hírnevüket és szerződéses garanciáikat iktatják be a folyamatba, egyszerüsítve a felhasználók mérlegelését.

Az állami hitelesítés legfontosabb eleme a fémzárolás, amely minden forgalmazott vetőmagra kötelezően vonatkozik, és számos funkciója van. Egyrészt egy államilag megszabott minőségi minimumot hitelesít, másrészt lehetővé teszi a vállalati és márkahírnév érvényesülését, megvédve a fajtatulajdonosokat és termelőket a hamisítástól. Ezzel egyben a vetőmagágazat kollektív hírnevét is segíti, azzal, hogy a fogyasztók fejében elválasztja az informális szektortól. A fémzárolt vetőmag eladási árában benne foglaltatik a fajtatulajdonos licencdíja, így hozzájárul a licencszerződések kikényszerítéséhez is.

A továbbszaporítás kontrollálása mindhárom tranzakció számára jelentős, de az értékesítésnél jelenik meg legélesebben, mert itt van jelen az informális modell alternatívája. Ez a személyes kapcsolatokkal megtámogatott közös moralitáson és hírnéven alapul, mivel a formális kikényszerítésre kevéssé tud hagyatkozni. Az informális és formális vetőmagágazat között komplementaritás is van (Almekinders \& Louwaars, 2002), amit esetünkben is elismertek a szereplők, mert előbbi olyan alacsonyabb vagy térségspecifikus minőségi igényeket fed le, amelyeket a formális ágazat nem feltétlenül képes profitábilisan megtenni. Ezt a megfontolást támasztotta alá jogilag az EUban is hatályos Farmers' Privilege szabályozás ${ }^{\text {iv }}$, amely kis mennyiségben, saját használatra engedélyezi a vetőmag továbbszaporítását. Ugyanakkor több szereplő is panaszkodott arra, hogy jelentős méretü termelök is törekedtek a licencdíjak megkerülésén keresztüli spórolásra. A problémára három fő megoldás született. Az első, technológiai megoldás a hibridizáció, amely garantálja a továbbszaporított vetőmag jelentős minőségromlását, így aláássa annak jövedelmezőségét. A nagyobb partnerekre vonatkozóan müködtetnek a fajtatulajdonosok saját ellenőrzési rendszert is, amely egyszerre alapul az együttmüködés normájának kialakításán és a szerződéses szankciókon. Ezt emeli közösségi szintre a Fajtaoltalmi Nonprofit Kft.

Az értékesítés a termelöi modellben passzol leginkább az imént leírt struktúrához. Ennek két fö eleme van, egyrészt a termelök közvetlenül értékesítenek a hírnevükre, személyes kapcsolataikra és formális szerződéses garanciákra hagyatkozva. A termelők ugyanakkor jelentős részben kereskedőn keresztül értékesítenek, igénybe véve annak hírnevét és kapcsolatait a gazdákkal. A fémzárolás és állami hitelesítés ennél a modellnél a legjelentősebb.

Az integrátori modell esetében is két eset lehetséges. Az első a termeltetés kapcsán leírt kvázi-integráció megoldása. Ekkor a termeltetői szerződéssel és a hasznok megosztásával összekötött hosszú távú kapcsolat áll a tranzakció mögött, kiegészítve az integrátor által nyújtott tanácsadással és ellenőrzéssel. A második esetben az integrátor kereskedőként, esetleg további kereskedőkön keresztül lép fel, vele közelebbi kapcsolatban nem álló gazdáknak értékesítve. Ez a viszony a termelö értékesítő helyzetéhez hasonlít, azzal a különbséggel, hogy az integrátor általában nagyobb, jobban ismert szereplő, így inkább tud a hírnevére hagyatkozni.

Az integrált nemesítooi vállalatok hagyományosan a közvetítő kereskedőkön keresztül értékesítettek, de a fajtatulajdonosok képviselöi egyre nagyobb mértékben veszik át a kereskedők funkcióit, így azok csak a logisztika és a pénzügyi kockázat kezelésében kapnak szerepet. Ennek fő oka a hosszú távú partnerségre hagyatkozás, ami arra ösztönzi a fajtatulajdonosokat, hogy minden jelentős vásárlójukkal megkíséreljenek személyes, egyénileg megállapított kedvezményeken, tanácsadáson és átfogó technológiai megoldásokon alapuló kapcsolatot kialakítani. A területi képviselők egyszerre próbálnak személyes hírnevet kiépíteni, valamint azzal alátámasztani a cég hírnevét.

\section{Vállalkozói szerveződések}

A vállalkozói szerveződések irányítási struktúrákban betöltött szerepeinek vizsgálatához először fel kell tárnunk a releváns szerveződéseket és intézményi mechanizmusaikat. Az ágazathoz kapcsolódva egy átfogó szakmaközi szerveződés, egy ügyspecifikus ágazati szerveződés és több szegmens-specifikus szerveződés található.

Vetőmag Szövetség Szakmaközi Szervezet és Terméktanács ${ }^{v}$ A Vetőmag Szövetség (VSZT) 1993-ban alakult meg a korábbi (kereskedői, termelői és nemesítői) szakmai szer- 
veződések összeolvadásával. A VSZT megalakulása óta törekedett arra, hogy a teljes ágazatot átfogó koordinációt valósítson meg. Tagsága ennek megfelelően vertikálisan átfogó, azaz a versenytársakén kívül az üzletfelek érintkezését is lehetővé teszi. A VSZT fő funkciója az információközvetítés volt az ágazaton belül, illetve a kormányzat és az ágazat között. Ezt a szerepét személyes találkozókon (bizottsági és elnökségi üléseken, küldöttgyüléseken és rendezvényeken), valamint rendszeres hírleveles és telefonos kapcsolattartáson keresztül tölti be.

Emellett intézményi tagságán keresztül a VSZT csatornázta be a magyar szereplőket a European Seed Asso-

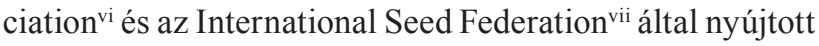
nemzetközi koordinációs, etikai és szakmai ellenőrzés, illetve vitarendezés kereteibe. A VSZT-t 1994-ben ismerte el a minisztérium Terméktanácsként ${ }^{\text {viii }}$, ami a kötelező tagságon és a hivatalos kormányzati hozzáférésen keresztül jelentős erőforrásokat biztosított számára. Az aktív részvétel fö ösztönzői az információhoz és a közös álláspontok kialakításához való hozzáférés voltak. A VSZT sikeresen építette ki hiteles információközvetítői szerepét. Ehhez arra volt szükség, hogy a szervezet vezetésében a különböző piaci szegmensek és vállalkozástípusok egyaránt képviselve legyenek, egy független titkársággal megtámogatva.

A kötelező tagság erős jogi alátámasztást adott a VSZT etikai ellenőrző szerepének, amely a formális, etikai kódexen és bizottságon keresztüli kikényszerítést kombinálja az informális, kiközösítéssel. A tagok szerint az etikai eljárást ritkán alkalmazzák, viszont jelentős eredményeket értek el a hamisítás visszaszorításában. A VSZT informális közösségi vitarendezőként is fellép, amennyiben a tagok és ügyfeleik rendszeresen panaszkodnak vezetöségének, elsősorban termékminőséggel és értékesítéssel kapcsolatos problémákról. A vezetőség ekkor kivizsgálja az ügyet, illetve informálisan segít a rendezésében, vagy az etikai bizottság elé utalja azt.

Az EU-csatlakozás nyomán a versenyjogi szabályozás elvárásait követve a VSZT szakmaközi szervezet formáját vette fel, amelyet a kormányzat 2014-ben ismert el ${ }^{\mathrm{ix}}$. Ez azzal járt, hogy a VSZT további garanciákat alakított ki a konszenzusos jellegére és az egyes szegmensek kiegyensúlyozott képviseletére vonatkozóan. A hivatalos elismerés jogi alapot adott a komolyabb koordinációs funkcióknak. Ezek közül legjelentősebb az irányárak éves meghatározása, amely több szereplő számára a VSZT legjelentősebb tevékenysége.

A VSZT a bejegyzett fajtákat összehasonlító (posztregisztrációs) kísérleteket szervez a szegmens-specifikus szerveződésekkel közösen. Ezek a kísérletek független, megbízható információt szolgáltatnak a fajták genetikai minőségéről.

A VSZT fontos szerepet töltött be a fémzárolt vetőmag elterjesztésében is. Ennek első eleme a kormányzattal közös tájékoztató kampány volt a gazdák meggyőzésére. A VSZT a nem fémzárolt vetőmaggal kapcsolatos ügyeket kizárja a vitarendezési tevékenységéből, ezzel a formális ágazat felé terelve a felhasználókat. Ezek részeredményei mellett kísérelte meg az ágazat a támogatáspolitikába be- építeni a fémzárolt vetőmaghasználat kitételét, csak részsikerrel járt, ugyanis egyedül a termelésalapú támogatás feltételrendszerében szerepel a fémzárolt vetőmaghasználat. ${ }^{x}$

Két további területen nem sikerült a felmerült kollektív célokat megvalósítani. Az első a vetőmag fémzárolásának jogosultságával kapcsolatos. Ezt az eredetileg állami funkciót az akkreditált laboratóriummal rendelkező cégek delegált jogkörben gyakorolhatták, azonban ezt a kormányzat a zöldségszegmens kivételével megszüntette, ami több szereplő szerint jelentős veszteségekkel járt. Ennek vélelmezhető oka az volt, hogy az ágazat egy része nem állt készen a delegált jogkör felelős alkalmazására. Ebböl felsejlik, hogy a delegált fémzárolás sikeres önszabályozása mellett megtarthatták volna a jogkört. Egy másik lehetséges ügy a „tisztességtelen” piaci magatartások szabályozása, ami alatt elsősorban a túltermelt vetőmag áron aluli értékesítését és más piacrontó gyakorlatokat értenek a felek. Az ügyben semmilyen konkrét megoldást nem sikerült azonosítani, ami abból is eredhet, hogy a nagy szereplők jelentős része nem ért egyet a piackorlátozással.

\section{Fajtaoltalmi Nonprofit ${ }^{x i}$}

A Fajtaoltalmi Nonprofit Kft-t (FN) 2009-ben, az európai uniós fajtaoltalmi szabályozás magyar jogba való átültetését követően alapította nyolc fajtatulajdonos. Célja a licencdíjak behajtása, illetve az ezzel kapcsolatos informális vitarendezés. Behajtási tevékenységét megalapozza, hogy megkönnyíti a gazdák számára a szaporítás bejelentését és a licencdíjak befizetését, illetve emlékezteti őket a kötelességeikre. Az FN elsődlegesen „fair play” alapon, etikai meggyőzéssel törekszik a kikényszerítésre ${ }^{\text {xii }}$, és csak szükség esetén fordul jogi szankciókhoz. A szerveződés inkluzív jellegü, valamint azonos jogokat biztosít az alapítóknak és a többi megbízónak, így a későbbiekben a fajtatulajdonosok nagy többsége csatlakozott hozzá. Az FN tevékenységét a beszedett licencdíjakból, arányosan fedezi, így külön ösztönzőre nem volt szükség a csatlakozáshoz. Elsősorban azok a fajtatulajdonosok maradtak kívül, amelyek partnereik válogatott köre miatt saját ellenőrzésüket hatékonyabbnak tartották a közösségi megoldásnál.

\section{Szegmens-specifikus szervezödések}

Az ágazati szerveződések harmadik csoportja a vertikális lánc mentén szerveződött egy-egy termék vagy tevékenység érintettjei számára, a genetikai minőség, mint közösen koordinálandó termékjellemző és a közös érdekképviselet igénye nyomán. Tagjaik lehetnek fajtatulajdonosok, integrátorok, vetömagtermelök és vetőmagfelhasználók, illetve a terményt felhasználó szereplők. Így túlnyúlnak a vetőmagszektoron, de fontosak a vetőmagosok számára is, mert a genetikai minőség kulcskérdés számukra is.

A Gabonatermesztők Országos Szövetségét ${ }^{x i i i}$ (GOSZ) 2004-ben alapították a gabona termesztésével foglalkozók, köztük vetőmagtermesztők, az EU-csatlakozással kapcsolatos információs és érdekképviseleti igény kielégítésére. A Magyar Kukorica Klubot ${ }^{\text {xiv }}$ (MKK) 2005-ben, szintén az EU-csatlakozás kihívásaival indokolva alapították a 
kukoricával foglalkozó termelők, információközvetítési céllal. A Magyar Szója és Fehérjenövény Egyesületet ${ }^{\mathrm{xv}}$ (MSZE) 2016-ban alapították a szójával és fehérjenövényekkel foglalkozó fajtatulajdonosok, vetőmagtermelők, termelők és feldolgozók, információmegosztási és érdekképviseleti célokkal.

A szegmens-specifikus szerveződések legfontosabb tranzakciós funkciója az információközvetítés. Ez leginkább a partnerek megismerését jelenti rendezvényeken és találkozókon keresztül. Szintén közös funkciójuk az információ biztosítása az egyes növényfajták minőségéről, amelyet elsősorban a posztregisztrációs kísérleteken keresztül intézményesítenek, gyakran a VSZT-vel közösen. Emellett etikai kontrollt gyakorolnak a tagjaik felett etikai kódexeiken és informális kikényszerítésen keresztül egyaránt.

\section{Szerzödéstámogató funkciók}

A 3. táblázat áttekintést ad a feltárt szerveződések szerződéstámogató funkcióiról. Elsődleges szerepük az információmegosztásban rejlik, ezt egészíti ki az informális vitarendezés és a szintén nagyrészt informális morális ellenőrzés. A VSZT és az FN a fémzárolás, míg a VSZT és a szegmens-specifikus szerveződések a posztregisztrációs kísérletek müködtetésében jelentősek. nagyon feltűnő normasértések esetén, ritkán került alkalmazásra. A ritka alkalmazás oka az elrettentés sikeressége is lehetett, de ezt kevesen gondolták így.

A szakmai ellenőrzés fő oszlopát jelentő állami minősítési rendszer támogatásában többen is kiemelték a szerveződések szerepét. A fémzárolást a felhasználók, az előállítók és a fajtatulajdonosok számára egyaránt védelmet jelentő, alapvető garanciának tekintik a szereplők, amely még a hosszú távú partnerségeken belül is hasznos szerepet tölt be. A VSZT fontos részeredményeket ért el a fémzárolás elterjesztésében, valamint a minősítési rendszer szakmai igényekkel való összehangolásában. Az FN a licencdíjak specifikus problémájára intézményesített egy relatív sikeres megoldást, amelyet majdnem minden fajtatulajdonos igénybe vesz.

A szakmai ellenőrzésben kiegészítő szerepet töltenek be a posztregisztrációs kísérletek. Egyes szereplők kifejezetten fontosnak tartották őket, ugyanakkor gyakran előfordult, hogy a legjelentősebb fajtatulajdonosok kimaradtak belölük, mivel nélkülük is hagyatkozhattak hírnevükre, így nem akarták esetleges rosszabb szereplésüket kockáztatni. A kísérletek így elsősorban a legnagyobbakat minőségben megközelítő, de kevésbé bevett hírnevü szereplők és újabb, nem kvázi-integrált partnereik számára szolgáltatnak hasznos információt.

3. táblázat A szerveződések szerződéstámogató funkciói

\begin{tabular}{|c|c|c|c|}
\hline Funkció & $V S Z T$ & $F N$ & Szegmens-specifikus \\
\hline morális szelekció & - & - & - \\
\hline szakmai szelekció & - & - & - \\
\hline morális ellenőrzés & etikai eljárás & - & etikai szabályok \\
\hline \multirow[t]{2}{*}{ szakmai ellenőrzés } & posztregisztráció & - & posztregisztráció \\
\hline & fémzárolás támogatása és szabályozás igénye & fémzárolás ellenőrzése & - \\
\hline vitarendezés & informális & peren kívüli díjbehajtás & - \\
\hline koordináció & irányárak & - & - \\
\hline információmegosztás & rendezvények, hírlevél, & - & rendezvények, hírlevél \\
\hline
\end{tabular}

Forrás: saját szerkesztés

\section{Vállalkozói szerveződések az irányítási struktúrákban}

Melyik szereplők és milyen szerződéses kapcsolataikban hagyatkoznak a vállalkozói szerveződések feltárt funkcióira?

Az információközvetitési funkció formalizált elemei elsősorban a kisebb vállalkozások számára jelentősek, mert a nagyok általában rendelkeznek saját csatornáikkal. A rendezvényeken és gyüléseken való személyes részvételen alapuló informális információmegosztás viszont szinte minden szereplő szemében fontosnak bizonyult.

Az irányárakon keresztül megvalósuló koordinációt a megkérdezettek egy része a VSZT fontos funkciójának tekintette, viszont a szerződéses kapcsolataik leírásánál nem hivatkoztak rá. Ennek fó oka az lehet, hogy a nagyobb fajtatulajdonosok és kereskedők egyedi alkukat kötnek a jelentős felhasználókkal, amelyekre csekély hatással vannak az irányárak.

A szerveződéseken keresztül megvalósuló etikai ellenörzés néhány szereplő szerint kifejezetten fontos volt a hamisítás visszaszorításában, de a többségük szerint csak a
Az informális vitarendezés a VSZT hasznos kiegészítő funkciójának bizonyult, elsősorban az értékesítési kapcsolatok esetében. Az FN tevékenységének alapja az informális vitarendezés, mivel csak a legritkább esetben fordul a formális jogi kikényszerítés mechanizmusaihoz. Ez a megoldás a fajtatulajdonosok és visszavető termelők nagy része számára hatékonyabbá teszi a licencdíjakkal kapcsolatos bizalom kialakítását (4. táblázat).

Mivel magyarázhatjuk a fenti mintázatot a vállalkozói szerveződésekre való hagyatkozásban? Az irányítási struktúrák négy másik elemével azonosítható összefüggés.

Minél távolabbi partnereket köt össze egy tranzakció, annál fontosabbak a szerveződések. Az integrált vállalkozások hierarchikusan oldanak fel tranzakciós problémákat, így kevésbé hagyatkoznak a szerveződések funkcióira. Az ezeken kívüli tranzakciók közül azok a szereplök hagyatkoznak legkevésbé a vállalkozói szerveződésekre, akik szaporítóként hosszú távú relációs szerződésekre vagy kvázi-integrációra hagyatkoznak. Az integrációk 
4. táblázat A szerveződések funkciói a tranzakciók irányítási struktúráiban

\begin{tabular}{|l|l|l|l|}
\hline \multicolumn{1}{|c|}{ Funkció } & \multicolumn{1}{|c|}{ Licencszerzödés } & \multicolumn{1}{c|}{ Termeltetési szerződés } & \multicolumn{2}{c|}{ Értékesitési szerzödés } \\
\hline Információmegosztás: rendezvények, hírlevelek & A hírnév megalapozásának nagyon fontos eleme \\
\hline Koordináció: irányárak & Közvetve segít a megegyezésben & \multicolumn{2}{|c|}{ Segít a megegyezésben } \\
\hline Etikai ellenőrzés: kódexek és informális kizárás & Kiegészítő szerep a normák artikulálásában és a kikényszerítésben \\
\hline Szakmai ellenőrzés: fémzárolás támogatása & Alapvető minőség garanciája & \multicolumn{2}{|c|}{ A hírnév és minőség nagyon fontos garanciája } \\
\hline Szakmai ellenőrzés: posztregisztráció & Fontos kiegészitő információ a genetikai minőségröl \\
\hline Vitarendezés: informális, formálissal kiegészítve & Kevéssé jellemző & \multicolumn{2}{|c|}{ Segít a felhasználói bizalom kialakításában } \\
\hline
\end{tabular}

Forrás: saját szerkesztés

központi szereplöi, az integrátorok és fajtatulajdonosok viszont aktív tagjai a vállalkozói szerveződéseknek. Ezt az magyarázza, hogy az integrátorok számos külső szereplövel is kapcsolatban állnak, amiben hagyatkoznak a vállalkozói szerveződésekre, illetve őket érinti legerősebben az állami szabályozás, amelyet a szerveződéseken keresztül befolyásolhatnak.

A kevésbé állandó és közeli partnerségek esetén az a kérdés, hogy mivel tudják kiegészíteni a felek a kétoldali megoldásokat. Itt minél kevésbé elérhetők egy szereplő számára az egyszerübb alternatívák, annál valószínűbb, hogy fontosnak tartja a szerveződéseken keresztül intézményesített mechanizmusokat. A közösségi kikényszerítésben második legkevésbé aktív szereplök azok, akik jól megválogatott partneri körrel, egyedi feltételek mellett szerződnek, általában a szabályozottnál jóval magasabb minőségű termékeket kínálva. A tágabb partneri körrel rendelkezők közül, akik a piaci reputációjuk alapján elérik a vevői körüket, azok kevésbé hagyatkoznak a vállalkozói szerveződésekre. A többi szereplő számára viszont a vállalkozói szerveződések fontos kiegészítő szerepet töltenek be a bizalom kialakításában.

A közvetítők és a vállalkozói szerveződések szerepe egyaránt akkor a legjelentősebb, amikor egy (kisebb, újabb) vállalkozás még nem képes a személyes kapcsolatokra és hírnevére alapozva elérni távolabbi partnereit. A közvetítő a saját hírnevére és kapcsolati megoldásaira hagyatkozva helyettesíti a vállalkozói szerveződéseket a felhasználókkal való szerződéses kapcsolatok esetén. Ugyanakkor a kereskedő és a neki értékesítő fél közötti kapcsolatban ugyanazok a korlátok jelennek meg, amelyekre a vállalkozói szerveződések mechanizmusai jelenthetnek megoldást, így kiegészítő viszony is fennáll. A vállalkozói szerveződések hozzájárulása a kikényszerítéshez elsősorban a kevésbé ismert partnerek esetén jelentős, és ezek a tranzakciók nagyrészt közvetítőn keresztül történnek.

Az állami szabályozásra hagyatkozó szereplök két okból hajlamosabbak a vállalkozói szerveződéseket is igénybe venni. A vállalkozói szerveződések koordinációs és ellenőrzési tevékenysége is nagyrészt minimumok megállapításán alapszik, amelyek egyaránt a nem teljesen piaci hírnév alapján működő érintettek számára relevánsak, még ha részben helyettesítik is egymást. Másrészt a vállalkozói szerveződések tevékenységének igen jelentős része az állami szabályozás minőségének javításán keresztül valósul meg, így kiegészíti az állami mechanizmusokat.

\section{Következtetések}

Az esettanulmány eredményei föbb vonalaikban igazolták a megfogalmazott elméleti sejtéseket, ugyanakkor felhívták a figyelmet egyes, korábbi elemzésekben kevésbé fajsúlyos tényezők jelentőségére. A vállalkozói szerveződések szerződéstámogató funkciói iránt támasztott keresletet jól magyarázzák a magán- és állami rend alternatív intézményeinek korlátai. A legerősebb kapcsolat a legközelebbi helyettesítőkkel, a tervezett magánrend intézményeivel, illetve a relációs mechanizmusokkal mutatkozik.

1. A vállalkozói szerveződésekre hagyatkozás és az üzleti kapcsolatok hosszú távú, relációs jellege, illetve a partnerek integrációjának mértéke között átváltás van. A vállalkozói szerveződések szerződések betartását kikényszerítő támogató funkciói elsősorban a rövid távú, piaci jellegű kapcsolatokban jelennek meg fontos tényezőként. A vezető szervezet által irányított kvázi-integrációs és a szerveződésen keresztül irányított hálózati forma közötti választást elsősorban a bizalom eloszlása és a kapcsolatok kiterjedése magyarázzák.

2. Szintén jelentős magyarázóereje lehet a hírnévalapú mechanizmusok jelenlétének. A vállalkozói szerveződésekre hagyatkozás és az üzletfelek piaci reputációja között részleges átváltás van. A vállalkozói szerveződések információközvetítő funkciója támogathatja a reputáció kiépítésén alapuló mechanizmusok működését, viszont a szerveződések ellenőrzési és vitarendezési tevékenysége a kisebb reputációjú cégek és partnereik számára fontosabb.

3. A piaci közvetítők alkalmazása kétféleképpen befolyásolja a vállalkozói szerveződések jelentőségét: egyrészt növelheti, amennyiben a közvetítők kapcsolataik kiépítésében hagyatkoznak a szerveződések funkcióira; másrészt csökkentheti, amennyiben a közvetítők kiterjesztik a szerveződések funkcióit kapcsolati és hírnévalapú szankciókkal helyettesítő, vezető szervezeten alapuló hálózati irányítási struktúra lehetőségeit.

4. Az állami rend mechanizmusaira való hagyatkozás növelheti a vállalkozói szerveződések jelentőségét, mivel a szerveződések csatornázzák be a vállalkozói közösségek igényeit a szabályozás tartalmával és a végrehajtási folyamatokkal kapcsolatban, megalapozva az állami mechanizmusok kiszámítható és szakmailag elfogadható müködését. Érdemes lehet a további elemzésbe bevonni az üzleti hálózatokon túlnyúló, kormányzati és magánszereplőket integráló szakmai hálózatokat. 
Bár jelen esettanulmányban ehhez nem állt rendelkezésre az intézményi jellemzők megfelelő varianciája, a további kutatás lehetséges irányaként a vállalkozói szerveződések intézményi formái (pl. önkéntesség és közjogi státusz, tagság jellege, nyitottság, vezetés és döntéshozatal) és funkcionalitása közötti összefüggések azonosítását ajánlanám a területtel foglalkozók figyelmébe.

\section{Felhasznált irodalom}

Almekinders, C. J. M., \& Louwaars, N. P. (2002). The Importance of the Farmers' Seed Systems in a Functional National Seed Sector. Journal of New Seeds, 4(1-2), 15-33. https://doi.org/10.1300/J153v04n01_02

Bakucs, Z., Fertő, I., \& Szabó, G. G. (2012). Benefits of a marketing cooperative in transition agriculture: Mórakert purchasing and service co-operative. Society and Economy, 34(3), 453-468. https://doi.org/10.1556/ SocEc.34.2012.3.6

Battisti, M., \& Perry, M. (2015). Small enterprise affiliations to business associations and the collective action problem revisited. Small Business Economics, 44(3), 559-576. https://doi.org/10.1007/s11187-014-9607-z

Bennett, R. J. (1998). Business associations and their potential contribution to the competitiveness of SMEs. Entrepreneurship \& Regional Development, 10(3), 243-260. https://doi.org/10.1080/08985629800000014

Bennett, R. J., \& Ramsden, M. (2007). The Contribution of Business Associations to SMEs: Strategy, Bundling or Reassurance? International Small Business Journal: Researching Entrepreneurship, 25(1), 49-76. https://doi.org/10.1177/0266242607071781

Bernstein, L. (1992). Opting out of the Legal System: Extralegal Contractual Relations in the Diamond Industry. The Journal of Legal Studies, 21(1), 115-157. https:// doi.org/10.1086/467902

Bernstein, L. (2001). Private Commercial Law in the Cotton Industry: Creating Cooperation Through Rules, Norms, and Institutions. Michigan Law Review, 99, 1724. https://doi.org/10.2307/1290478

Besser, T. L., \& Miller, N. (2011). The structural, social, and strategic factors associated with successful business networks. Entrepreneurship \& Regional Development, 23(34), 113-133. https://doi.org/10.1080/08985620903183728

Biró S., Rácz K., Csörnyei Z., Hamza E., Varga E., Bene E., \& Miskó K. (2015). Agrár- és vidékfejlesztési együttmüködések Magyarországon (Biró S. \& Rácz K., Szerk.). Budapest: Agrárgazdasági Kutató Intézet.

Borbély, S. (2001). Nemzetközi üzleti hálózatok Magyarországon. Európai Tükör, 6(4).

Broadman, H. G., Anderson, J., Claessens, C. A., Ryterman, R. S., Slavova, S., Vagliasindi, M., \& Andronova Vincelette, G. (2004). Buildings market institutions in South Eastern Europe: Comparative prospects for investment and private sector development (Sz. 29301). Elérés forrás The World Bank website: http://documents.worldbank.org/curated/ en/132241468051250898/Buildings-market-institutions-in-South-Eastern-Europe-comparative-prospects-for-investment-and-private-sector-development
Buanec, B. L. (2002). The Rules for International Seed Trade. Journal of New Seeds, 4(1-2), 143-153. https:// doi.org/10.1300/J153v04n01 11

Buanec, B. L., \& Heffer, P. (2002). The Role of International Seed Associations in International Policy Development. Journal of New Seeds, 4(1-2), 77-87. https:// doi.org/10.1300/J153v04n01_06

Burer, S., Jones, P. C., \& Lowe, T. J. (2008). Coordinating the supply chain in the agricultural seed industry. European Journal of Operational Research, 185(1), 354-377. https://doi.org/10.1016/j.ejor.2006.12.015

Doner, R. F., \& Schneider, B. R. (2000). Business Associations and Economic Development: Why Some Associations Contribute More Than Others. Business and Politics, 2(03), 261-288. https://doi.org/10.2202/14693569.1011

Eisenhardt, K. M. (1989). Building Theories from Case Study Research. The Academy of Management Review, 14(4), 532-550. https://doi.org/10.2307/258557

Eisenhardt, K. M., \& Graebner, M. E. (2007). Theory Building from Cases: Opportunities and Challenges. The Academy of Management Journal, 50(1), 25-32. https://doi.org/10.5465/amj.2007.24160888

Fertő, I. (2012a). Bizalom és szerződéses kapcsolatok a magyar élelmiszerláncban. In I. Fertő \& J. Tóth (szerk.), Piaci kapcsolatok és innováció az élelmiszergazdaságban (pp. 133-144). Budapest: Aula. (https:// www.econstor.eu/handle/10419/108256).

Fertő, I. (2012b). Szerződések kikényszeríthetősége a magyar élelmiszerláncban: A kis- és közepes vállalkozások esete. In I. Fertő \& J. Tóth (szerk.), Piaci kapcsolatok és innováció az élelmiszer-gazdaságban (pp. 157-170). Budapest: Aula. (https://www.econstor.eu/ handle/10419/108256).

Fertő, I., \& Bakucs, L. Z. (2012a). Hogyan tudnak a termelők bekapcsolódni a modern élelmiszerláncokba. In I. Fertö \& J. Tóth (szerk.), Piaci kapcsolatok és innováció az élelmiszer-gazdaságban (pp. 17-33). Budapest: Aula. (https://www.econstor.eu/handle/10419/108256).

Fertő, I., \& Bakucs, Z. (2012b). Szerződéses kapcsolatok az élelmiszerláncban és a szerződések kikényszeríthetösége. GAZDÁLKODÁS: Scientific Journal on Agricultural Economics, 56(6). Elérés forrás https://econpapers.repec.org/article/agsgazdal/143601.htm

Francis, D. C., Karalashvili, N., \& Murrell, P. (2018). Mapping the Landscape of Transactions: The Governance of Business Relations in Latin America. https://doi. org/10.1596/1813-9450-8564

Gehrig, T., \& Jost, P.-J. (1995). Quacks, lemons, and self regulation: A welfare analysis. Journal of Regulatory Economics, 7(3), 309-325. https://doi.org/10.1007/ BF01067100

Ghijsen, H. C. H. (2002). Property Rights on Plant Varieties: An Overview. Journal of New Seeds, 4(1-2), 195-212. https://doi.org/10.1300/J153v04n01_15

Ghoshal, S., \& Bartlett, C. A. (1990). The Multinational Corporation as an Interorganizational Network. Academy of Management Review, 15(4), 603-626. https:// doi.org/10.5465/amr.1990.4310825 
Greif, A. (2002). Institutions and Impersonal Exchange: From Communal to Individual Responsibility. Journal of Institutional and Theoretical Economics (JITE) / Zeitschrift für die gesamte Staatswissenschaft, 158(1), 168-204. https://doi.org/10.1628/0932456022975538

Greif, A. (2008). Commitment, Coercion and Markets: The Nature and Dynamics of Institutions Supporting Exchange. In C. Ménard \& M. M. Shirley (Szerk.), Handbook of New Institutional Economics (pp. 727786). https://doi.org/10.1007/978-3-540-69305-5_29

Harzing, A.-W. (1999). Managing the multinationals: An international study of control mechanisms. E. Elgar.

Hendley, K., \& Murrell, P. (2003). Which mechanisms support the fulfillment of sales agreements?: Asking decision-makers in firms. Economics Letters, 78(1), 49-54. https://doi.org/10.1016/S0165-1765(02)00177-5

Hendley, K., Murrell, P., \& Ryterman, R. (2000). Law, Relationships and Private Enforcement: Transactional Strategies of Russian Enterprises. Europe-Asia Studies, 52(4), 627-656. https://doi.org/10.1080/713663079

International Seed Federation. (2016). Exports of seed for sowing by country - Calendar year 2016. Elérés forrás https://www.worldseed.org/wp-content/uploads/2018/03/ Exports_2016_Final.pdf

Izsáki, Z., \& Lázár, L. (2004). Szántóföldi növények vetőmagtermesztése és kereskedelme. Elérés forrás https:// www.tankonyvtar.hu/hu/tartalom/tkt/szantofoldi-novenyek/index.html

Jensen, M. C., \& Meckling, W. H. (1976). Theory of the Firm: Managerial Behavior, Agency Costs and Ownership Structure. Journal of Financial Economics, 3(4). Elérés forrás https://papers.ssrn.com/abstract $=94043$

Johnson, S., McMillan, J., \& Woodruff, C. (2002). Courts and Relational Contracts. Journal of Law, Economics, \& Organization, 18(1), 221-277. https://doi. org/10.1093/jleo/18.1.221

Kumar, S., \& Ali, J. (2010). Indian agri-seed industry: Understanding the entrepreneurial process. Journal of Small Business and Enterprise Development, 17(3), 455-474. https://doi.org/10.1108/14626001011068734

Lane, C., \& Bachmann, R. (1997). Co-operation in InterFirm Relations in Britain and Germany: The Role of Social Institutions. The British Journal of Sociology, 48(2), 226-254. https://doi.org/10.2307/591750

Lazzarini, S. G. (2004). Order with Some Law: Complementarity versus Substitution of Formal and Informal Arrangements. Journal of Law, Economics, and Organization, 20(2), 261-298. https://doi.org/10.1093/ jleo/ewh034

Louwaars, N. P. (2002a). Seed Policy, Legislation and Law: Widening a Narrow Focus. Journal of New Seeds, 4(1-2), 1-14. https://doi.org/10.1300/J153v04n01_01

Louwaars, N. P. (2002b). Variety Controls. Journal of New Seeds, 4(1-2), 131-142. https://doi.org/10.1300/ J153v04n01_10

Macaulay, S. (1963). Non-Contractual Relations in Business: A Preliminary Study. American Sociological Review, 28(1), 55. https://doi.org/10.2307/2090458
McCormick, L. E., Hawley, J. D., \& Meléndez, E. (2008). The Economic and Workforce Development Activities of American Business Associations. Economic Development Quarterly, 22(3), 213-227. https://doi. org/10.1177/0891242408321694

McMillan, J., \& Woodruff, C. (2000). Private Order under Dysfunctional Public Order. Michigan Law Review, 98(8), 2421-2458. https://doi.org/10.2307/1290349

Ménard, C. (2004). The Economics of Hybrid Organizations. Journal of Institutional and Theoretical Economics (JITE) / Zeitschrift für die gesamte Staatswissenschaft, 160(3), 345-376. Elérés forrás JSTOR.

Ménard, C. (2013). 26. Hybrid Modes of Organization Alliances, Joint Ventures, Networks, and Other Strange Animals. In R. Gibbons \& J. Roberts (szerk.), The Handbook of Organizational Economics (pp. 10661106). https://doi.org/10.1515/9781400845354-028

Mike K. (2018). A hitelesség táguló körei szerződéskikényszerítő intézmények és a vállalkozások növekedése. Vezetéstudomány / Budapest Management Review, 49(2), 2-11. https://doi.org/10.14267/VEZTUD.2018.02.01

Mike K., Boza I., \& Molnár G. T. (2018). A vállalkozói szerveződések mint szerződéstámogató intézmények. Egy magyar vállalati felmérés tanulságai. In Valentiny P., Kiss F. L., Nagy C. I., \& Berezvai Z. (szerk.), Verseny és Szabályozás 2017 (pp. 62-90). Budapest: MTA KRTK Közgazdaság-tudományi Intézet.

Mike, K., \& Kiss, G. (2018). Combining formal and informal contract enforcement in a developed legal system: A latent class approach. Journal of Institutional Economics, 2018, 1-17. https://doi.org/10.1017/ S1744137418000425

Monteiro, G. F. A., \& Zylbersztajn, D. (2015). Heterogeneity of Property Rights Strategies in A Global Context: The Case of Genetically Modified Soybean Seeds: Heterogeneity of Property Rights Strategies. Global Strategy Journal, 5(1), 69-83. https://doi.org/10.1002/ gsj.1091

Murrell, P. (2003). Firms facing new institutions: Transactional governance in Romania. Journal of Comparative Economics, 31(4), 695-714. https://doi.org/10.1016/j. jce.2003.08.002

North, D. C. (1990). Institutions, institutional change, and economic performance. Cambridge ; New York: Cambridge University Press.

Nugent, J. B., \& Sukiassyan, G. (2009). Alternative Strategies for Firms in Oppressive and Corrupt States: Informality or Formality Via Business Associations? Contemporary Economic Policy, 27(4), 423-439. https:// doi.org/10.1111/j.1465-7287.2009.00171.x

Perry, M. (2009). A new look at industry associations as effective enterprise networks. International Journal of Entrepreneurship and Small Business, 8(2), 259. https://doi.org/10.1504/IJESB.2009.024380

Poppo, L., \& Zenger, T. (2002). Do formal contracts and relational governance function as substitutes or complements? Strategic Management Journal, 23(8), 707725. https://doi.org/10.1002/smj.249 
Provan, K. G., \& Kenis, P. (2008). Modes of Network Governance: Structure, Management, and Effectiveness. Journal of Public Administration Research and Theory: J-PART, 18(2), 229-252. Elérés forrás JSTOR.

Prüfer, J. (2016). Business Associations and Private Ordering. The Journal of Law, Economics, and Organization, 32(2), 306-358. https://doi.org/10.1093/jleo/ ewv017

Pyle, W. (2005). Contractual Disputes and the Channels for Inter-firm Communication. Journal of Law, Economics and Organization, 21, 547-575. https://doi. org/10.1093/jleo/ewi014

Pyle, W. (2006). Resolutions, recoveries and relationships: The evolution of payment disputes in Central and Eastern Europe. Journal of Comparative Economics, 34(2), 317-337. https://doi.org/10.1016/j.jce.2006.02.002

Spulber, D. F. (1999). Market Microstructure: Intermediaries and the Theory of the Firm. Cambridge University Press.

Szabó, G. G. (2010). The importance and role of trust in agricultural marketing co-operatives. Studies in Agricultural Economics, 112, 1-20.
Szabó G. G., \& Baranyai Z. (2017). A szövetkezés-együttmüködés gazdasági és társadalmi akadályai, makroés mikrogazdasági feltételei, valamint fejlesztési lehetöségei a magyar élelmiszer-gazdaságban. Budapest: Agroinform Kiadó.

Tucker, A. (2008). Trade Associations as Industry Reputation Agents: A Model of Reputational Trust. Business and Politics, 10(1), 1-26. https://doi.org/10.2202/14693569.1218

van der Meer, C. (2002). Public-Private Cooperation. Examples from Agricultural Research in the Netherlands. In D. Byerlee \& R. G. Echeverría (Szerk.), Agricultural research policy in an era of privatization. Elérés forrás dx.doi.org/10.1079/9780851996004.0000

van Gastel, T. J. G., Gregg, B. R., \& Asiedu, E. A. (2002). Seed Quality Control in Developing Countries. Journal of New Seeds, 4(1-2), 117-130. https://doi.org/10.1300/ J153v04n01_09

Williamson, O. E. (1979). Transaction-Cost Economics: The Governance of Contractual Relations. The Journal of Law and Economics, 22(2), 233-261. https://doi. org/10.1086/466942

\footnotetext{
${ }^{i}$ Forrás: International Seed Federation. (https://www.worldseed.org/about/what-we-do/ Elérés: 2018.03.01.)

ii INTERNATIONAL CONVENTION FOR THE PROTECTION OF NEW VARIETIES OF PLANTS. Revised at Geneva on March 19, 1991.

iii NÉBIH. [2016.09.23.] Vetőmag-szaporítás szántóföldi ellenőrzésének módszertana [https://portal.nebih.gov.hu/-/vetomag-szaporitas-szantofoldi-ellenorzesenek-modszertana Elérés: 2018.02.01.]

iv A Tanács 2100/94/EK rendelete [1994. július 27.]

${ }^{v}$ Vetőmag Szövetség - Terméktanács. (http://www.vszt.hu/hu/rolunk/bemutatkozas.html Elérés: 2018.01.11.)

${ }^{v i}$ European Seed Association. (https://www.euroseeds.eu/general-info Elérés: 2018.02.03.)

vii International Seed Federation. (https://www.worldseed.org/about/what-we-do/ Elérés 2018.02.01.)

viii Földművelésügyi Minisztérium 2/1994. TT határozata

ix Agrárgazdaságért Felelős Államtitkár ApF/5-4/2014. határozata

$\times$ 9/2015. (III. 13.) FM rendelet

xi Fajtaoltalmi Nonprofit Kft. [2017]. Bemutatkozás. (http://www.fss.hu/index.php?option=com_content\&view=article\&id=56\&Itemid=204 Elérés: 2018.02.01.)

xii Fajtaoltalmi Nonprofit Kft. [2010]. Fair play. (http://www.fss.hu/index.php?option=com_content\&view=article\&id=60\&Itemid=220 Elérés: 2018.02.01.)

xiii Gabonatermesztők Országos Szövetsége. (http://www.gabonatermesztok.hu/ Elérés: 2018.02.02.)

xiv Magyar Kukorica Klub (https://www.magyarkukoricaklub.hu/ Elérés: 2018.02.03.)

${ }^{x v}$ Magyar Szója és Fehérjenövény Egyesület. (https://magyarszoja.hu/ Elérés: 2018.03.18.)
} 